\title{
The Influence Of Personal Selling And Quality Products To Purchase Decision
}

\author{
Muhammad Andi Prayogi' ${ }^{1}$, Sri Fitri Wahyuni², Lukman Hakim Siregar ${ }^{3}$, Muhammad Taufik \\ Lesmana $^{4}$, and Asrizal Efendy Nasution ${ }^{5}$ \\ \{muhammadandi@umsu.ac.id ${ }^{1}$ \} \\ 1,2,4,5 University of Muhammadiyah Sumatera Utara, Jalan Kapten Mukhtar Basri No. 3 Medan, Indonesia \\ ${ }^{3}$ University of Dharmawangsa, Indonesia
}

\begin{abstract}
The strategy of personal selling and product quality is the means used to increase consumer purchases. This study aims to analyze simultaneously between personal selling and quality of product to decision simpati card purchases in the city of Medan.The method used in this research is quantitative method by using techniques NonProbability Sampling, which is a sampling technique that does not provide opportunities or equal opportunity for each element or member of the population to be selected into the sample. It is based on the types of accidental sampling (accidental) that anyone who happens to see or wear a simpati cardtotaling 70 samples. The technique of analyzing the the data used in this research was multiple linear regression. The results of this analysis, personal selling and product quality and significant positive influence on purchasing decisions simpati card in Medan. The implication of this research is further enhanced promotion methods and the quality of existing products in order to face the competition between existing competitors.
\end{abstract}

Keywords: personal selling, quality product, purchase decision

\section{Introduction}

Before the advent of telecommunications equipment, pigeons used as a tool for the delivery of letters, pigeons were taught to be able to convey a message or news. Use of the telegram in the delivery of the news was very long due to the arrival time and when the telegram until we wondered what news there, guessing whether good or bad news. In the era of the 1980s to get information quickly difficult to obtain, but at the present time it is easy to access all the information we need quickly. The emergence of communication tools greatly assist in the speed of information delivery. Along with advances in technology and rapid turnaround and globalization increasingly complex may have an impact on changes in the field of life, especially those in the field of telecommunications.

Today the use of cellular phones is not a scarce and expensive, but there are necessities for everyone. Their cellular phone facilitate the delivery of information quickly without waiting too long. As the times many cellular phone providers that offer cheap packages with a term speak a different call, one of which is a product of Telkomsel's cellular network. Telkomsel of Indonesia's leading company is a subsidiary of PT. Telekomunikasi Indonesia (PT. Telkom). Most serious mobile operator Telkomsel became the 6th in the world with 125 million subscribers in 2012. The large number of customers due to Telkomsel has an extensive range that covers all provinces, districts and all of the districts in Indonesia which are hallmarks of Telkomsel than its competitors.Telkomsel output products include Halo cards, 
simpati cards and aces. Each has its own advantages in its use. Simpati is output from Telkomsel card that is widely used by the public, but if it is not maintained vitur-vitur there then people will switch to another provider. One can still make the products remain in demand is the method of sale and product quality. Sales force plays an important role in introducing or selling products. One way to introduce a product that is most effective and is still believed until now is by way of personal selling.

Personal selling is an oral presentation in a conversation with one or several potential buyers for the purpose of sale (Saladin, 2006, p. 172), Promotion through personal selling is done in a way to meet directly with consumers where the salesperson explain the features of the product to consumers later formed consumer understanding of the product so that then they will try to buy it. Personal selling is needed in efforts to achieve the desired goal, because the method of delivery is an attempt to be what the information can be conveyed to the public, especially to consumers about the existence of a product. Success in achieving the capability information is influenced by marketers to convey short messages, clear and attractive to consumers. In addition to personal selling, support of quality products should also be considered to form the satisfaction of the consumer and create profits for the company. Improved results of a product made by a company, the level of satisfaction perceived by consumers to be high. Thus it can be said that the purchasing decisions made by consumers affected by the sale through personal selling and the quality of the product itself. Thus, manufacturers are required promotion well and can improve the quality of its products in order to know what consumers want and stimulate consumer purchasing decisions. The development of consumer protection movement has made an urgent demand to understand how consumers create Reviews their consumption and purchasing decisions. Consumers' tastes and favorites are rapid changing. In conclusion, consumer behavior helps in constructing of production policy. "For effective market segmentation and targeted marketing, it is important to have knowledge of consumers and their purchase decision (Khuong and Duyen, 2016). "

In terms of promotions, the company incentive to do various activities. One of the activities carried out by PT. Cellular Telecommunications Terrain are selling face to face (personal selling) with consumers. However, various strategies implemented by PT. Cellular telecommunications field in the simpati card marketing efforts in the area of Medan which includes several schools and colleges have not been sufficiently able to guarantee the continuity of consistent sales of the company. That previous studies conducted in PT. Cellular Telecommunications discovered the occurrence of sales, things that are causing the problem, among others, intense competition in the telecommunications industry, where consumers are faced with a wide selection of quality products so diverse that influence consumer purchase decisions. Besides the cost of personal selling in the implementation of an obstacle in marketing at PT. Cellular telecommunications, it can happen because in practice marketers costly for the success of the personal selling them prepare for the cost of uniforms to be used salespeople, preparing the items that are in containers are attractive and so forth. Besides the cost, the ability of salespeople also be one of the problems, because consumer behavior is influenced by various factors and marketers need to make adjustments in order to then consumers will try to buy it. Today, people are more conscious about the brand than the past. "There are number of cues present in the environment that your public in selection. One of them is branding. "" It is a mental shortcut Considered more powerful in selection. A brand can notice the influence of consumer products Whether or not (Oladepo and Abimbola, 2015, page. 98). "Selling is a process in which what the needs of a buyer and sales needs can be met, the exchange of information and interests. The main factor of a company buying or selling of seeing their quality or quality (Nasution, Prayogi and Affandy, 2017, p. 61). 
Herman (2012, p. 105) states "Sales of personal (face to face) is a direct communication between the seller and potential customers to introduce a product to potential customers and establish customer understanding of the product that will then try and buy it." According to Tjiptono (2012, p. 376)"Personal selling is an integral component in integrated marketing communications and is not a substitute for other elements of the promotional mix." According Kotler (2007, p. 72) personal selling is an oral presentation in a conversation with one or several potential buyers for the purpose of making a sale. According to Baduara and Sirait (2014, p. 60), A good personal selling is the leadership and initiatives such as: "1) He knew clearly what the real purpose. 2) He can formulate a practical plan to achieve those goals 3) He can put people who have knowledge and experience needed to carry out that purpose. 4) $\mathrm{He}$ has confidence in the results of what has been planned, even though the plan had not begun to be implemented. 5) He did not back down no matter how hard the difficulties and challenges he encountered, because he thought any bad situation there must be a way out. 6) He did not try to grope in making plans but look for facts to be the basis of all the plans. 7) He does not abandon plans and goals due to the influence of others.

Sales promotions can include techniques that organisasi Reviews their use as part of the marketing effort (Jobber and Lancaster, 2006). The indicators of personal selling by Swashta (2008, p. 260) is as follows: "1) Approach Introduction 2) Percentage and Demonstration 3) Overcoming Rejection 4) Closing the Sale Transaction 5) Follow-up." According to Kotler and Armstrong (2008, p. 25) personal selling indicators are as follows: "1) Face to Face to the Customer. 2) Be Friendly to the Costumer. 3) Provide Explanation of the Product. 4) Handle customer objections. 5) Ask for customer orders. "Kotler and Keller (2008) explains that the dimensions of quality products such as the quality of performance, the level of entry into force of the characteristics of the product basics. Quality suitability, level of conformity and fulfillment of all units produced to the specifications of the promised target. Age Tahan.ukuran expected power over the operation of the product under normal conditions and / or weight, is a valuable attribute for certain products. Reliability measure of the probability that a certain set of products that will not be damaged or fail within a certain time period. Easily fixed. Easily remedied is a measure of the ease to repair the product when it is damaged or fails. Style, describes the appearance and the feeling by the product to the buyer. As researchdo Sulaiman, (2017), Rajagukguk, (2017) showed a positive and significant product bahwakualitas to increased sales volume. Quality products, is one of the main factors in determining the decision to buy a product (Kristian and Widayanti, 2016, p.46), Consumer satisfaction is something that is constantly being met by the manufacturer. To create a consumer satisfaction, manufacturers must understand the factors that create satisfaction (Mahendra, 2014, p.283), One factor is the quality of the product.

According to Kotler (2009 pages. 350), while the indicator of the quality of the products used as a basis for planning the company are: 1) The form, 2) Features, 3) Quality of performance, 4) Quality conformity, 5) Durability, 6) Reliability, 7) Easily fixed, 8) Style, 9) Draft. In purchasing decisions, consumers actions on a variety of alternative actions that are owned, decision- making is a process that starts from the recognition that problems can be solved through the purchase of some products (Brata, Husani, and Ali, 2017, page. 435), Consumer purchase decision is Behaviors Showed by decision- making units in the buying, usage and disposal of goods and services. Consumer purchase decision is the decision- making process and physical activity when individuals engage in evaluating, acquiring, using or disposing of goods and services (Khuong and Duyen, 2016, page.44), A buying decision process (or cost-benefit analysis) describes the process a customer goes through when buying a product (Altekar, and Keskar, 2014, page. 113). 


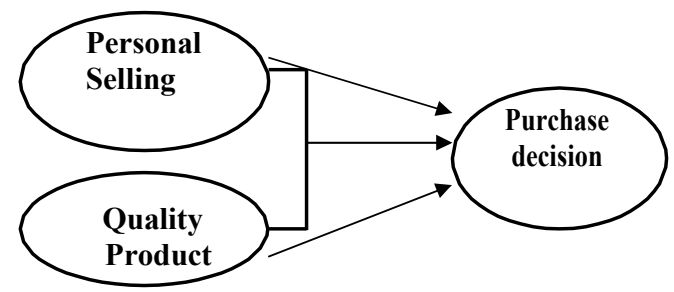

Fig.1. Conceptual Framework

The hypothesis of this study: H1: Personal Selling influence the buying decision Simpati Cards. H2: Quality Product Purchasing Decisions affecting Simpati Cards. H3: Personal Selling and Product Quality simultaneously influence the purchase decision Simpati Cards.

\section{Research Methods}

This study uses a quantitative method, using techniques Non-Probability Sampling, ie sampling technique which does not give an opportunity or equal opportunity for each element or member of the population to be selected into the sample. It is based on the types of accidental sampling (accidental) that anyone who happens to see or wear a simpati card numbering 70. The technique of analyzing the the data used in this research was multiple linear regression. Validity testing is done by using product moment correlation technique; all items were valid instrument Before conducting multiple linear regression testing, classical Assumptions were used firstly (normality test, Heterosecurity, and multicollinearity). Thus Spake the classical asumsic regression models in this test could be fulfilled.

\section{Result And Discussion}

The results of multiple linear regression tested using the Statistical Package for Social Sciences (SPSS), obtained as shown in Table 1.

Table 1. T-Test Results (parcial)

\begin{tabular}{|c|c|c|c|c|c|c|c|}
\hline & & Coef & nts $^{\mathrm{a}}$ & & & & \\
\hline & del & Unst & ardized & Standardized & & $\mathrm{t}$ & Sig. \\
\hline & & B & Std. Error & Beta & & & \\
\hline 1 & (Constant) & -1.500 & 2.762 & & & -.543 & .589 \\
\hline & $\begin{array}{l}\text { Personal } \\
\text { Selling }\end{array}$ & .384 & .163 & & .234 & 2.351 & .022 \\
\hline & Quality Product & .444 & .085 & & .518 & 5.207 & .000 \\
\hline
\end{tabular}

a. Dependent Variable: Purchase Decision

The equation regression analysis shown in table 1 above is $\mathrm{Y}=\alpha+\beta \mathrm{x} 1+\beta \mathrm{x} 2+\mathrm{E}$ so that the beta value added in the regression equation $\mathrm{Y}=-1.500+0.384+0.444+\mathrm{e}$, this equation can be interpreted; if the variable increases and assuming personal selling product quality variables unchanged, the purchase intention will decrease. If the Product Quality variable increases, the assumption of Personal Selling variables unchanged, the purchase intention will decrease. In other words, Personal Selling should be raised by the company to increase the 
interest of the buyer. Furthermore, to answer the hypothesis was partially based on Table 1, the results Hypothesis 1: X1 Variable (Personal Selling) t 2.351, so that $\mathrm{t}$ count $>\mathrm{t}$ table $(2.351>1.994)$. Statistically, X1, Personal Selling) influenced variable Y (Purchase Decision), or the hypothesis is accepted. This means that the majority of Personal Selling significantly influenced purchasing decisions with significant value was $0.022<0.05$. Hypothesis 2: Variable X2 (Product Quality) t 5.207, so that t count $>$ t table $(5.207>1.994)$. Statistically, X2 (Product Quality) is influenced variable Y (purchase decisions), or the hypothesis is accepted. Product Quality is affected most significantly by the decision to buy a significant value is $0.000<0.05$. X2 (Product Quality) is influenced variable Y (purchase decisions), or the hypothesis is accepted. Product Quality is affected most significantly by the decision to buy a significant value is $0.000<0.05$. X2 (Product Quality) is influenced variable $\mathrm{Y}$ (purchase decisions), or the hypothesis is accepted. Product Quality is affected most significantly by the decision to buy a significant value is $0.000<0.05$.

Table 2. Simultaneous Test Result (F test)

\begin{tabular}{llrllll}
\hline \multicolumn{6}{c}{ ANOVA $^{\mathrm{a}}$} \\
\hline Model & Sum of Squares & df Mean Squar & $\mathrm{F}$ & Sig. \\
\hline 1 & Regression & 70.222 & 2 & 35.111 & 17.165 & $.000^{\mathrm{b}}$ \\
\cline { 2 - 6 } & Residual & 137.050 & 67 & 2.046 & \\
\cline { 2 - 6 } & Total & 207.271 & 69 & & & \\
\hline \multicolumn{2}{l}{ a. Dependent Variable: Purchase Decision } \\
\hline
\end{tabular}

The table above Showed the results of Hypothesis 3, the simultaneous influence of X1 (Personal Selling), X2 (Quality Product) towards Y (Purchase Decision), it was Obtained the F count value was 17.165 with a probability value $(\mathrm{sig})=0,000$. F count $(17.165)>\mathrm{F}$ table (3.98), with significant value $<0.05$ or $0.000<0.05$; then the hypothesis was accepted, it meant that Personal Selling and Product Quality simultaneously had a significant influence towards Simpati Card Purchase Decision.

Table 3. Result of The Coefficient Determination.

\begin{tabular}{|c|c|c|c|c|c|c|}
\hline Model & $\mathrm{R}$ & R Square & $\begin{array}{l}\text { Adjusted R } \\
\text { Square }\end{array}$ & $\begin{array}{l}\text { Std. Error of the } \\
\text { Estimate }\end{array}$ & $\begin{array}{l}\text { Sig. F } \\
\text { Change }\end{array}$ & $\begin{array}{l}\text { Durbin- } \\
\text { Watson }\end{array}$ \\
\hline 1 & $\begin{array}{r}.58 \\
2^{\mathrm{a}}\end{array}$ & .339 & .319 & 1.43022 & .000 & 1.551 \\
\hline \multicolumn{7}{|c|}{ a. Predictors: (Constant), Quality Product, Personal Selling } \\
\hline
\end{tabular}

The Output Model Summary in Table 3, it is known that R Square (R2) value is 0.339, the magnitude of $\mathrm{R}$ Square 0.339 is equal to $33.90 \%$. This figure means that personal selling and quality products Affect purchase decision of $33.90 \%$. While the rest $(100-33.90=$ $66.10 \%)$ is influenced by other variables beyond this regression models. The magnitude of the effect of other variables is Referred to an error (e).

\section{Discussion}

Partially personal selling positive and significant impact on purchasing decisions simpati card. The product quality is also positive and significant impact on purchasing decisions 
simpati card, visible beta value of 0518 which explained that the quality of products influence on purchase decisions by consumers simpati card. Simultaneously, personal selling and product quality significantly influence the purchase decision simpati card is visible from the $\mathrm{F}$ test $($ ANOVA) that $F$ count $>F$ table $(17.165>3.98)$. The implication of this research is that companies should improve product quality and marketing methods are not only using persomal selling,

\section{Conclusion}

Research carried out aimed at providing answers to the increase in purchases made by a consumer. From the research shows that the factor of personal selling and product quality determine the simpati card purchasing decisions by consumers. The biggest contribution of the research is the quality of the product as a determinant in purchasing decisions. In doing promotion strategies should be improved in how the method of sale, how a marketing tells the features of a product, its advantages compared to competitors' products, not only was the friendly attitude and a smile is also a technique in marketing a product. Limitations in this study only examined the variables of personal selling and product quality that can determine a consumer's purchasing decision as well as the number of samples totaling 70 samples. Expected later there is another variable and the number of samples for further research could be more varied and more, so that later can serve as input to the management in the process of evaluation of the resulting product in order to achieve the set targets.

\section{References}

[1] Adesoga, A. (2016) 'Examination of the Relevance of Personal Selling in Marketing Activities: a Descriptive Method.', Journal of Accounting and Management, 6(2), pp.103-115.

[2] Altekar, S., and Keskar, A. (2014) 'A Study of the Factors Impacting the Buying', Journal of General Management Research, 1(2), pp. 111-123.

[3] Anyadighibe, J. A., Awara, N. F. and Esu, B. B. (2014) 'The impact of personal selling on the productivity of selected banks in Calabar Metropolis', International Journal of Development and Sustainability, 3(8), pp. 1697-1708.

[4] Baruna Hadi Brata, Shilvana Husani, and H. A. (2017) 'a Comparative Study on Development Off Small and Medium Enterprises (Smes) in Japan and Malaysia', Saudi Journal of Business and Management Studies, 2(4B), pp. 433-445. doi: 10.21276/sjbms.

[5] Baduara, Sotar dan Sabar Martin Sirait (2014). Personal Sellingship. Jakarta, PT. Bumi Aksara

[6] Djoni; Oktaviani, R.; K. (2016) 'Factors that Affect the Sales Performance of PT SKP ( A Case Study of Sales Force of Moorlife Indonesia in Jabodetabek )', Indonesian Journal of Business and Entrepreneurship, 2(2), pp. 122-129.

[7] Enitilo, O. (2017) 'Influence of Promotional Activities on Consumers' Patronage of Insurance Business in Ado Ekiti Metropolis , Nigeria', V(1), pp. 414-436.

[8] Isaac Oladepo, O. and Samuel Abimbola, O. (2015) 'the Influence of Brand Image and Promotional Mix on Consumer Buying Decision-a Study of Beverage Consumers in Lagos State, Nigeria', British Journal of Marketing Studies, 3(4), pp. 97-109. doi: 2053-4051.

[9] Jolson, M. A. (1997) 'Broadening the Scope of Relationship Selling Broadening the 
Scope of Relationship Selling', XVII(4), pp. 75-88.

[10] Khuong, M. N. and Duyen, H. T. M. (2016) 'Personal Factors Affecting Consumer Purchase Decision towards Men Skin Care Products - A Study in Ho Chi Minh City, Vietnam', International Journal of Trade, Economics and Finance, 7(2), pp. 44-50. doi: 10.18178/ijtef.2016.7.2.497.

[11] Kotler \& Keller (2007). Manajemen Pemasaran. Terjemahan PT. Indeks, Edisi Duabelas, Jilid Satu, PT. Macanan Jaya Cemerlang

[12] Kotler, Philip \& Garry Armstrong (2008). Prinsip-prinsip Pemasaran. Terjemahan Bob Sabran. Edisi Duabelas .Jilid Satu. Jakarta: PT. Erlangga

[13] Kristian, denny, rita, W. (2016) 'Keputusan Pembelian Sepeda Motor Honda Pada Mahasiswa Kampus 1 Universitas Kristen Krida Wacana', Jurnal Ilmiah Manajemen Bisnis, 16(1), pp. 45-58.

[14] Mahendra, S. (2014) 'Pengaruh Kualitas Produk dan Harga Terhadap Kepuasan Konsumen Honda Beat', Jurnal Ilmu Manajemen, 2(1), pp. 282-292.

[15] Muchina, C. M. and Okello, B. (2016) 'Influence of Personal Selling on Brand Performance of Retail Shoe Companies in Nairobi Central Business District', International Journal of Academic Research in Business and Social Sciences, 6(5), pp. 1-14. doi: 10.6007/IJARBSS/v6-i5/2113.

[16] Muhanji, E. M. and Ngari, B. (2015) 'Influence of Integrated Marketing Communication and Sales Performance of Commercial Banks in Kenya', 5(9), pp. 120.

[17] Nasution, M. I., Prayogi, M. A., \& Nasution, S. M. A. (2017). Pengaruh Kualitas Produk, Promosi Terhadap Penjualan Pada usaha Mikro Pengrajin Sepatu Di Kecamatan Medan Denai. InProsiding SNaPP2017Sosial, Ekonomi, dan Humaniora (pp. 60-70). Bandung: Universitas Islam Bandung.

[18] Rajagukguk, P. (2017). Analisis kebijakan produk dan promosi terhadap volume penjualan. In Konferensi Nasional Ilmu Sosial \& Teknologi (KNiST) (pp. 473-478).

[19] Saladin, Djaslim (2006). Manajemen Pemasaran. Bandung: Linda Karya.

[20] Sulaiman. (2017). Pengaruh Kualitas Produk dan Pelayanan Dalam Meningkatkan Volume Penjualan Marisamart Dimarisa. Jurnal Ilmiah KARIMAH STIE AMKOP Makassar, 2(2), 169-178.

[21] Shrivastava, Neha ; Singh, R. P. (2017) 'Copyright (C) 2017, Scholarly Research Journal for Interdisciplinary Studies', Scholarly Research Journal for Interdisciplinary Studies, 4(35), pp. 6410-6420.

[22] Tjiptono, Fandy dan Gregorius Chandra (2012). Pemasaran Strategic. Edisi Kedua. Yogyakarta : Andi.

[23] T. Nugroho and U. Sumarwan, "Factors Influencing the Purchase Decision of Organic Tofu," Indonesian Journal Business Entrepreneurshi p, vol. 1, no. 3, pp. 115-126, 2015.

[24] Villamor, A. P. C. and Arguelles, R. M. (2014) 'Personal Selling and Social Media: Investigating their Consequences to Consumer Buying Intention', International Conference on Business, Management and Corporate Social Responsibility (ICBMCSR'14) Feb. 14-15, 2014 Batam (Indonesia), pp. 41-44. doi: 10.15242/ICEHM.ED0214024

[25] Yousif, R. O. (2016) 'The Impact of Personal Selling on the Purchasing Behavior towards Clothes: A Case Study on the Youth Category', International Journal of Marketing Studies, 8(5), pp. 128-135. doi: 10.5539/ijms.v8n5p128. 
